DEPÓSITO LEGAL ZU2020000153

Esta publicación científica en formato digital

es continuidad de la revista impresa

ISSN 0041-8811

E-ISSN 2665-0428

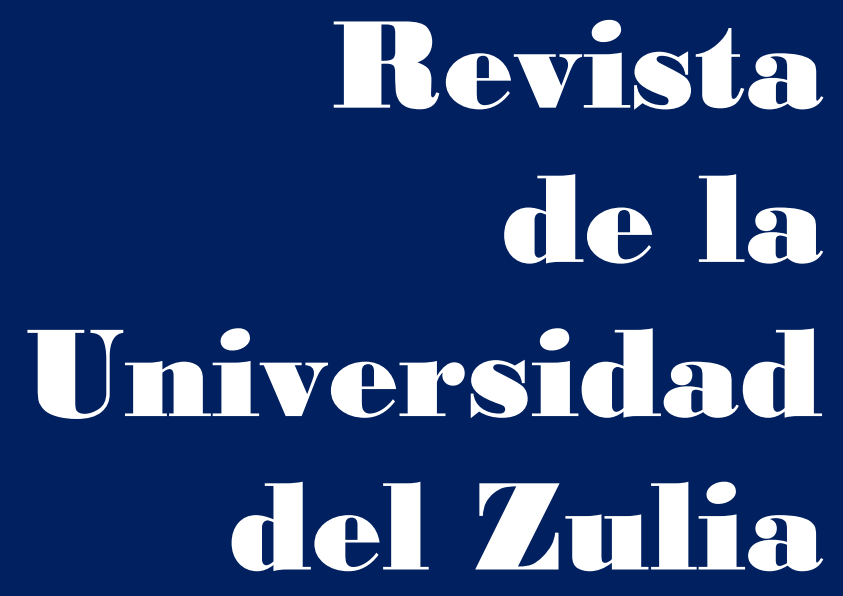

Fundada en 1947

por el Dr. Jesús Emrique Lossada

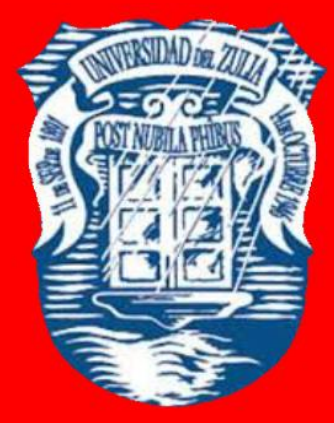

Ciencias

Sociales

y Arte

Año $12 \quad N^{\circ} 34$

Septiembre - Diciembre 2021

Tercera Época

Maracaibo-Veneruela 


\title{
Business activity of enterprises as a factor in accelerating technological progress in the economy
}

\author{
Lyudmila M. Putyatina * \\ Gennady V. Tikhonov** \\ Lyudmila A. Lavrova *** \\ Natalia V. Arsenieva ****
}

\begin{abstract}
The article deals with the problems of increasing the commercial activity of machinebuilding companies in post-crisis conditions, the solution of which should contribute to a fairly rapid return to previously developed plans for their expansion. The relevance and novelty of the problem lies in an integrated approach to the category of commercial activity of companies, which involves investigating various areas of their activities and generalizations from the theoretical and practical point of view. The objective of the study is to identify possible ways to increase the commercial activity of companies to enter the development stage. The methodological basis of the study is based on work in the field of economics, management and finance of companies and the possibility of its use in modern conditions. The main directions of research into the commercial activity of companies are analyzed: ensuring planned growth and improving the material and technical base of production; balance and steady increase in financial results; increase in the efficiency of the use of all types of resources of the company and its work in general; effective policy of deepening specialization and diversifying production; and growth of innovative potential in all areas of activity.
\end{abstract}

KEY WORDS: enterprises; growth rate; economic and social development; resources management; economic growth.

* Moscow Aviation Institute (National Research University). Moscow, Russia. ORCID: https:/orcid.org/0000-0002-3050-1477. E-mail: putyatinal@gmail.com

**Moscow Aviation Institute (National Research University). Moscow, Russia. ORCID: https://orcid.org/0000-0001-8502-0235. E-mail: gennadytikhonov@mail.ru

***Moscow Aviation Institute (National Research University). Moscow, Russia. ORCID: https:/orcid.org/0000-0003-4435-9165. E-mail: mati-fac6@mail.ru

**** Moscow Aviation Institute (National Research University). Moscow, Russia. ORCID: https://orcid.org/0000-0003-4265-6254. E-mail: natars2002@mail.ru 


\section{La actividad comercial de las empresas como factor de aceleración del progreso tecnológico en la economía}

\section{RESUMEN}

El artículo trata sobre los problemas del aumento de la actividad comercial de las empresas de construcción de maquinaria en condiciones posteriores a la crisis, cuya solución debería contribuir a un retorno bastante rápido a los planes previamente desarrollados para su expansión. La relevancia y novedad del problema radica en un enfoque integrado a la categoría de actividad comercial de las empresas, que implica investigar diversas áreas de sus actividades y generalizaciones desde el punto de vista teórico y práctico. El objetivo del estudio es identificar posibles formas de incrementar la actividad comercial de las empresas para entrar en la etapa de desarrollo. La base metodológica del estudio se fundamenta en trabajos en el campo de la economía, la gestión y las finanzas de las empresas y la posibilidad de su uso en las condiciones modernas. Se analizan las direcciones principales de la investigación de la actividad comercial de las empresas: el aseguramiento del crecimiento planificado y la mejora de la base material y técnica de la producción; equilibrio y aumento constante de los resultados financieros; aumento de la eficiencia del uso de todo tipo de recursos de la empresa y su trabajo en general; política eficaz de profundización de la especialización y diversificación de la producción; y crecimiento del potencial innovador en todos los ámbitos de actividad.

PALABRAS CLAVE: empresa; tasa de crecimiento; desarrollo económico y social; gestión de recursos; crecimiento económico.

\section{Introduction}

Business activity of machine-building enterprises is a particularly promising modern category that allows enterprises to implement their strategic development plans and ensure innovative economic growth in a fairly fast time frame.

Business activity of enterprises is ensured primarily by the stability of their development and the balance of economic growth in the future.

The subject of the study in this case is an integrated approach to the business activity of machine-building enterprises in modern conditions. The importance of the study is determined by the need for restoration and active forward movement along the path of further development of enterprises in the post-crisis period. 
In modern studies, considerable attention is paid to the concept of business activity of enterprises, most often in certain areas, for example, increasing production efficiency, building up innovative potential (Pinkovetskaia et al, 2021).

In this regard, the purpose of this study is to focus on the multidimensionality of this concept for a detailed study of individual areas in practice.

Business activity is addressed very often to the internal factors of the enterprise: increase in production capacity, renewal of labor instruments, technologies, etc. However, the modern economy also requires active work with the external environment of the enterprise, which is interpreted as market activity (Abramsky, 2001; Abryutina and Grachev, 2001).

It is not enough to produce a competitive product, but it is equally important to position it in industry and in international environment, which gives an appropriate assessment not only to the product, but also to its developers and manufacturers.

If we generalize all modern definitions of the business activity of enterprises, it can be formulated as the ability of an enterprise to achieve the planned economic growth and development with the widespread use of the entire range of extensive and intensive methods of increasing the efficiency of its activities.

Economic growth and development are fairly close concepts, but they have different specifics. The economic development of business entities is based on ensuring their economic growth and determined on the basis of the quantitative characteristics of the enterprise (Poloskov and Zheltenkov, 2018; Putyatina and Arsenyeva, 2020; Zverev et al, 2021).

In the most general sense, economic growth is a quantitative increase with a qualitative improvement of the social product over a certain period of time (usually a year).

The economic growth of an enterprise is determined, first of all, by the growth of such indicators as: amount of products manufactured in physical terms, revenue, profit, etc. However, in real conditions, the growth of some indicators may be accompanied by stability or even a decrease in others (for example, the company's revenue increased, and the balance sheet profit decreased due to an increase in the cost of production) (Putyatina and Arsenyeva, 2020).

\section{Literature Review}


The term "business activity" appears in Russian literature relatively recently, in connection with the reform of the economy and the formation of market relations.

Currently, there are a large number of interpretations of the concept of "business activity". However, they all have their flaws and do not characterize business activity comprehensively. So, in the large economic dictionary, business activity is understood as "economic activity, concretized in the form of the production of a particular product or the provision of a specific form of service and forms the basis of the international standard classification of economic sectors and economic classifiers of the System of National Accounts" (Azrilian, 2004).

The most famous Russian authors are V.V. Kovalev, G.V. Savitskaya, etc. The methodology for analyzing business activity proposed by them is based on the same indicators, but there are differences in the depth of the analysis.

The most detailed analysis of business activity, covering all aspects of the enterprise, is given by V.V. Kovalev (2007).

In addition to the usual indicators of business activity, such as the turnover of working capital and its components and the period of their turnover, it includes in the analysis of business activity indicators of the efficiency of the use of enterprise resources: material, labor and financial one (Kovalev and Volkova, 2000).

O.V. Myasnikova considers business activity as a set of work of all employees of an enterprise, whose efforts are aimed at increasing the turnover of working resources and assets (Myasnikova, 2007).

The main difference between foreign approaches and the approaches of Russian authors lies in their practical content, they are filled with specific examples and experience of firms. E. Helfert under business activity means the efficient use of assets entrusted by the owners to the managers of the company. There is also a close relation between the business activity of organizations and the functioning of the securities market. Thus, D. Stone and K. Hitching present business activity as a characteristic of the effectiveness of managing a company's asset portfolio (Stone and Hitching, 2009).

\section{Materials and Methods}

When implementing the strategy of economic growth, it is important for enterprises to consider such important areas as: increasing the material and technical base of production, 
i.e. the amount of resources involved, which form the basis of the economic potential of enterprises; increasing the efficiency of resource use based on the intensification of production processes; identification and active use of reserves for increasing the efficiency of all production and commercial activities of the enterprise; systematic implementation of a comprehensive innovation policy, involving the introduction of new and modernized goods, technologies, deepening of specialization and expansion of production cooperation.

The methodological basis of the study is modern scientific developments in the field of management, enterprise economics, innovation management, marketing, etc.

The procedure for researching the business activity of enterprises should be divided into two main parts: identification of the weakest points in the activities of the enterprise that require active intervention and development of specific measures to eliminate these shortcomings.

Unfortunately, it is rather difficult to develop a comprehensive quantitative assessment of the business activity of enterprises, since each enterprise has its own development program, its own opportunities for economic growth, specifics of innovation processes, etc.

Therefore, one of the main indicators of the business activity of the enterprise is the timely fulfillment of the set strategic goals and development tasks for the studied period of time.

It must be emphasized that economic growth and development are not the same thing. Growth can happen with or without development. Growth is an increase in certain indicators of enterprise: revenue, asset value, etc.

The concept of enterprise development refers not so much to quantitative fundforming indicators of growth and financial results of enterprises as to qualitative changes in the field: goods with improved technical and operational indicators, indicators of reliability, ergonomics, cost, etc.; production technologies that reduce labor intensity while improving product quality; management methods that allow, based on the methods of the digital economy, to make more balanced, most optimal decisions in the development of production and in the process of selling products; social policy of enterprises, which allows the most effective use of the main element of the driving force of progress: staff of enterprises, taking 
REVISTA DE LA UNIVERSIDAD DEL ZULIA. 3é época. Año $12 \mathrm{~N}^{\circ}$ 34, 2021

Lyudmila M. Putyatina et al. /// Business activity of enterprises as a factor in accelerating ... 133-149

DOI: http://dx.doi.org/10.46925//rdluz.34.09

into account the increase in their interest in the results of labor (Bank, V. R., Bank, S. V. and Taraskina, 2006).

It should be noted that the economic growth of indicators always has a certain limit due to the limitation of the resources used by the enterprise, therefore, the modern task of the development of enterprises is based on systematic and balanced growth, ensuring technical and economic progress in science and production (Voitolovsky, Kalinina and Mazurova, 2013).

When considering economic growth in detail, the following areas of analysis for enterprises are often highlighted:

- time, at which the dynamics of the most important indicators in time for the studied period of time is determined, taking into account the rate of their change.

- $\quad$ industry, which determines the importance of an enterprise in the industry and the output of industry products;

- $\quad$ social, which provides social guarantees for the employees of the enterprise when the macroeconomic conditions change (level of employment, crisis, inflation, etc.).

- innovative, in which a policy of improving the quality of products, their competitiveness, regular updating of technologies, means of labor, etc. is implemented.

\section{Research Results}

The factors and directions that determine business activity of enterprises in modern conditions are shown in the Figure 1.

We consider the above areas of research of enterprises' business activity in more detail.

Systematic growth and improvement of the material and technical base of production (fixed and circulating assets, staff). The growth of factors of production is the starting point for the development of enterprises, since they provide the basis for increasing their production capacity and allow expanding the horizons of specialization and diversification of production in the future. An increase in the resources used by an enterprise in its activities is an important factor in extensive development, but does not exclude the active use of intensive factors.

Balanced and consistent increase in the financial results of the enterprise. With an increase in production factors, it is not possible to obtain sufficiently fast return in the form of an increase in revenue and profit in practice. However, these indicators determine the 


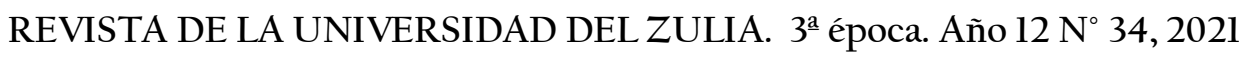

Lyudmila M. Putyatina et al. /// Business activity of enterprises as a factor in accelerating ... 133-149

DOI: http://dx.doi.org/10.46925//rdluz.34.09

effectiveness of growth and the purpose of carrying out various measures to improve the material and technical base of production.

Figure 1. Factors and directions that determine the business activity of enterprises in modern conditions

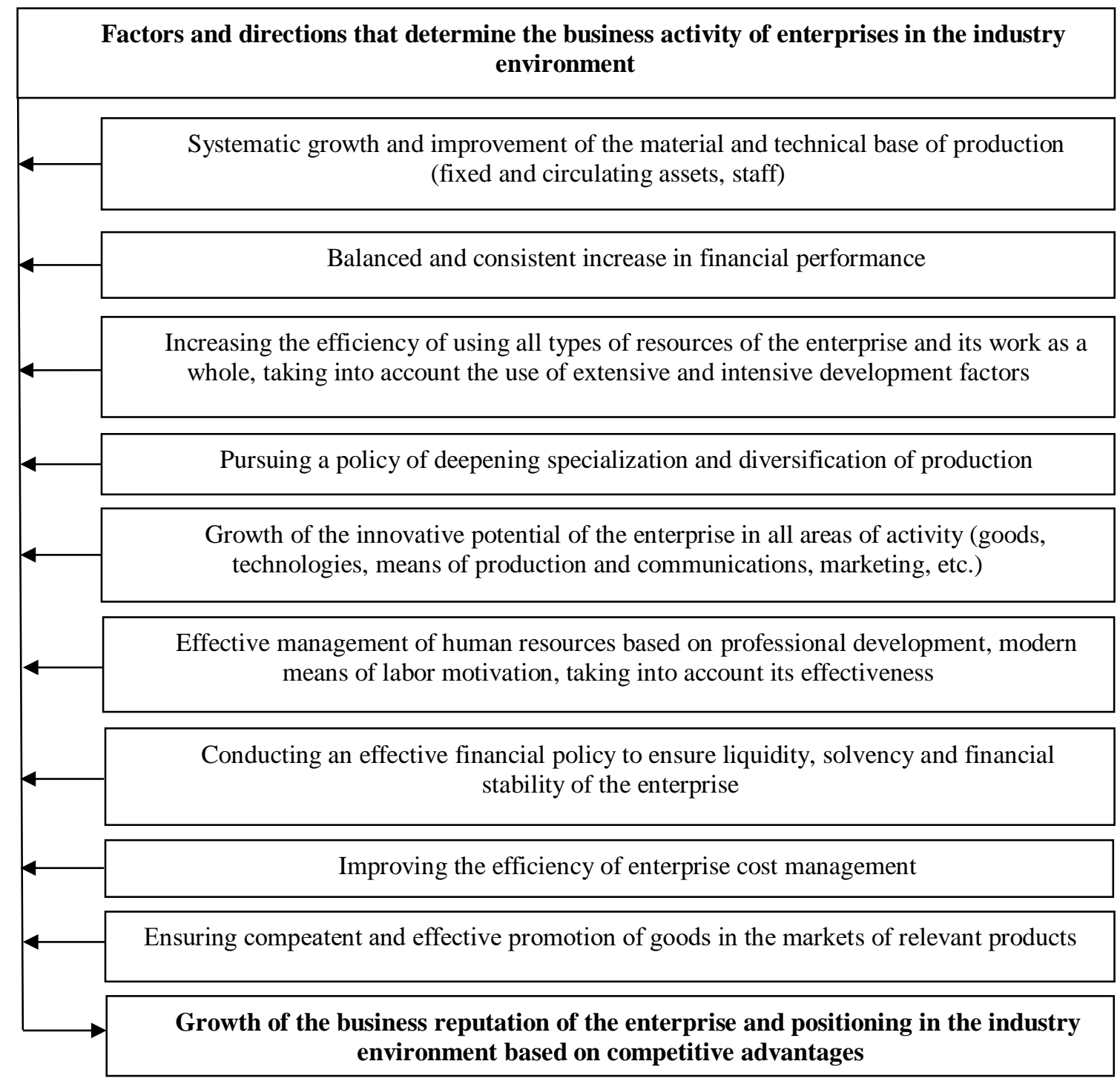

Improving the efficiency of using all types of resources of the enterprise and its work as a whole, taking into account the use of extensive and intensive development factors. When developing an enterprise, as a rule, both methods are used, depending on the availability of funds for development. The efficiency of the enterprise is determined mainly by the indicators of profitability (assets, fixed and working capital, sales, etc.). All indicators of profitability with an increase in the efficiency of the enterprise should have a growth trend (Helfert, 2008). 
Pursuing a policy of deepening specialization and diversification of production. Modern enterprises mainly have industry specialization, which is associated with the release of products for a specific purpose. In connection with the industry cooperation used in the manufacture of complex products, enterprises may have the following types of specialization: subject, involving the release of ready-to-use products of the enterprise; detailed, focused on the release of individual parts, assemblies, etc.; technological, which is focused on performing certain technological operations as separate types of production activities (metallurgical production) (Atkisson, 2015).

Along with the development of specialization, enterprises are also diversifying their activities, which is understood as a self-regulating process of expanding the capabilities of an enterprise in various directions, most of which are interconnected and interdependent (Novikov, 2018).

The main types of diversification of the enterprise are given in the Table 1.

Table 1. Main types of diversification of enterprises

\begin{tabular}{|c|c|}
\hline Diversification type & Scope of use \\
\hline $\begin{array}{l}\text { Diversification } \\
\text { production }\end{array}$ & $\begin{array}{l}\text { Expansion of nomenclature and assortment of products } \\
\text { by the enterprise }\end{array}$ \\
\hline $\begin{array}{l}\text { Diversification of capital } \\
\text { investment }\end{array}$ & $\begin{array}{l}\text { Distribution of financial resources in various innovative } \\
\text { projects or an investment fund between securities with } \\
\text { different returns and risks }\end{array}$ \\
\hline $\begin{array}{l}\text { Diversification of industrial } \\
\text { cooperation }\end{array}$ & $\begin{array}{l}\text { Expansion of the sphere of economic relations for the } \\
\text { supply of components and semi-finished products }\end{array}$ \\
\hline Diversification of market & Expansion of sales markets for manufac \\
\hline $\begin{array}{l}\text { Diversification of } \\
\text { technology }\end{array}$ & $\begin{array}{l}\text { Expansion of the technologies and know-how used by } \\
\text { the enterprise }\end{array}$ \\
\hline Diversification of industry & $\begin{array}{l}\text { Expansion of the sphere of economic relations and } \\
\text { introduction into other industries }\end{array}$ \\
\hline
\end{tabular}

The main reasons and goals for the development of diversification at enterprises may be the following ones: enterprise with difficulties in selling the current range of products; most of the goods are at the stage of decline in the life cycle; need for the most complete use of production facilities (due to their complete or partial downtime); high level of competition in the market for relevant goods and there are analogous goods (including imported ones) 


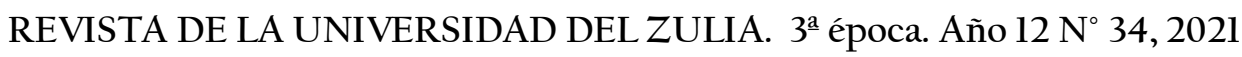

Lyudmila M. Putyatina et al. /// Business activity of enterprises as a factor in accelerating ... 133-149

DOI: http://dx.doi.org/10.46925//rdluz.34.09

that quickly capture the market; company purposefully reduces the risk of dependence on the market conditions for certain products, etc.

There are certain types of industrial diversification that are of the greatest importance for machine-building enterprises, which are reflected in the Figure 2.

Figure 2. Main types of diversification of production

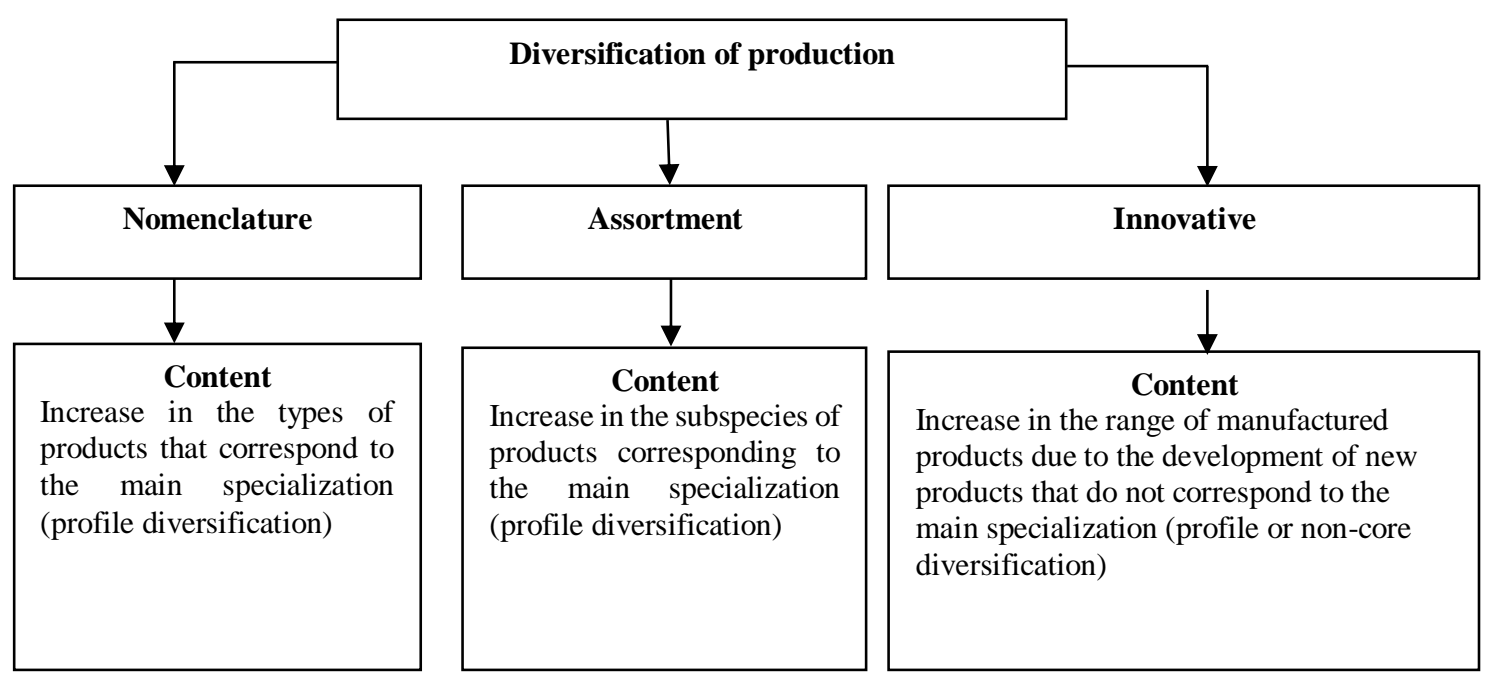

Growth of the innovative potential of the enterprise in all areas of activity (goods, technologies, means of production and communications, marketing, etc.)

Today, each enterprise has a certain experience in introducing innovations (goods, technologies, materials, labor instruments, etc.), i.e. it has a certain innovative potential.

In the most general approach, the innovative potential of an enterprise should be understood as the ability to develop and implement various innovations that provide:

- $\quad$ improving the quality of manufactured goods (structures) based on the main technical and economic characteristics;

- $\quad$ expansion of the range of products by means of new types;

- introduction of new technological processes, equipment, materials, organizational forms of labor and management, etc.

The innovative activity of modern machine-building enterprises has many conditions for development, determined by:

- $\quad$ interest and financial support from the state and industry;

- $\quad$ financial well-being of the enterprises themselves, which have a sufficiently high level of self-financing; 
- $\quad$ programs to stimulate scientific and technical developments in the field of mechanical engineering;

- $\quad$ presence and development of intellectual property.

The introduction of promising innovations provides the enterprise not only experience in their development, but also the prospect of their development for a long period of time. The more actively the development of various innovations at the enterprise takes place, the higher its innovative potential and its business activity is (Komarova, Zamkovoi and Novikov, 2019).

Effective management of human resources based on professional development, modern means of labor motivation, taking into account its effectiveness.

The staff of enterprises is extremely important in the economy of any enterprise, since it largely determines the following: economic growth of enterprises for the production of competitive products in accordance with world achievements; development and implementation of a wide range of innovations: goods, technologies, methods of organizing production, use of modern means of labor; growth in labor productivity as an important factor in the intensification of production; introduction of innovative projects to update the material and technical base of production; increasing the efficiency of production and economic activities of enterprises in general; widespread use of the digital economy in their activities and other aspects.

Conducting an effective financial policy to ensure liquidity, solvency and financial stability of the enterprise.

Assessment of the financial condition of enterprises is an important component of its business activity, since it determines the level of their financial independence, the degree of loyalty of credit relations in the banking system and in relations with industry partners (Petrova, 2020). This problem is urgent because many enterprises have difficulties in replenishing working capital for development and are often not always able to repay the loans taken on time and in full, which greatly complicates the rhythm of production and sales of products.

In the process of financial and economic analysis we evaluate: 
- $\quad$ rate of growth of the property of the enterprise, characterizing the expansion of economic activity, as well as the mobility of assets, which is determined by the ratio of non-current and circulating parts in the structure;

- $\quad$ level of liquidity of the company's assets, which largely determines the level of its solvency;

- level of financial stability, which is divided into absolute financial stability, normal, unstable financial position and crisis financial position;

- $\quad$ level of financial independence, which is mainly determined by the equity concentration ratio;

- financial indicators of business activity and efficiency of economic activity. Improving the efficiency of enterprise cost management.

In the conditions of market competition, each manufacturer must commensurate his costs for the production and sale of products with the market opportunities, effective demand of buyers and costs of the main competitors. For this it is necessary to calculate and timely adjust the cost of goods, which can constantly change under the influence of internal production and external market factors (Kiselev, 2006).

In a modern economy, the efficiency of cost management is the determining element of the economic and financial policies of enterprises. The cost management process includes:

- $\quad$ planning, control and adjustment of the cost of all types of products;

- $\quad$ analysis of the structure of the cost of goods and its changes;

- determination of economies of scale of production in the production of technologically similar products for the optimal adjustment of pricing policy;

- $\quad$ study the impact of changes in inflation on costs and other aspects.

It is important to refract numerous changes in production through adjusting costs, which is extremely important for the development of a company's pricing policy for the future.

Ensuring competent and effective promotion of goods in the markets of relevant products.

The conditions for the accelerated development of the Russian economy are accompanied by a significant degree of uncertainty of market changes in the external environment of enterprises. 
In this situation, a promising marketing task is not only taking into account these changes, but also, to a large extent, the impact on the external environment and active participation in its formation. When enterprises follow the laws of market orientation, they are forced to take into account the interests of not only direct customers (consumers) of products, but also intermediate customers and even competitors.

In the conditions of effective marketing, the enterprise closely interacts with the external environment, i.e. the market in the broadest sense of the word should be informed about the enterprise and its products, and the enterprise takes into account the specifics of the market conditions of individual manufactured goods to the maximum.

Marketing costs are very important for the activities of enterprises, since they directly affect the level of overhead costs, production costs and their financial results (Efimova and Melnik, 2009).

In general, the effectiveness of activities and costs associated with marketing can be determined by various factors and indicators, for example, growth of:

1. regular customers and buyers of products;

2. revenue from individual goods and enterprise as a whole;

3. profits from the sale of products by type and by enterprise;

4. relative reduction in unit costs associated with the implementation of marketing and other activities.

Growth of the business reputation of the company and positioning in the industry environment based on competitive advantages.

The market stability of an enterprise is determined by its ability to fairly quickly restructure to changes in market needs and market conditions, building up and demonstrating its competitive advantages in the industry environment.

The conclusions of the analysis of the market stability of the enterprise should contain the following main elements:

- to what extent the company is able to maintain its main specialization in an unstable economic environment and what are the main economic reasons and consequences of the changes that have occurred;

- to what extent the production potential of the enterprise is able to develop, update and modernize its products; 
- what is the level of competitiveness of manufactured products in Russian market and is there potential for its increase;

- what competitive positions the company has achieved and what strategic goals the company can implement to strengthen or increase the achieved level;

- what is the financial stability of the enterprise and its stock, which is possible when building long-term plans;

- what are the potential adaptations of the enterprise to possible changes in the market conditions of goods, etc.

\section{Discussion}

In view of the urgent need for enterprises, first of all, the restoration of the level of economic activity to the pre-crisis level, there is a problem of the minimum period for carrying out the relevant measures, which is quite controversial. In these conditions each company individually assesses its damage and develops its own plan for returning to previously set goals.

The timing of bringing enterprises to the pre-crisis level today is quite difficult to determine, however, due to the qualifications and creative initiative of staff at the enterprises, planned calculations are already being made to adjust the production program for the next period of time, taking into account the intensification of business activity (Khotinskaya, 2018).

According to experts, the recovery period can last from 1 to 3 years (Dontsova, 2015).

Since modern machine-building enterprises have a high level of cooperation in production, their ability to overcome the crisis is directly related to the work of related enterprises to provide the necessary semi-finished products and components.

An important element of their activities is their regular production diversification, which can solve the problem of the fullest use of production capacities, as well as the employment of staff during the recovery period.

Debatable is the question of deepening specialization or using production diversification. Various researchers try to justify these methods from different angles. However, it is practically impossible to get an unambiguous answer to this question, since it depends on the development of the market conditions in new conditions and the accumulated experience in the production of the company's products (Khotinskaya, 2018). 
The planned and implemented innovative projects of enterprises can be largely suspended or ranked according to the terms of development due to the limited or lack of funding.

The primary tasks of enterprises in the current conditions, requiring an integrated approach and increased business activity, should be considered: ensuring expedient planned work in the formation of the product range; consistent increase in the efficiency of the resources used and the enterprise as a whole; rational promotion of innovative projects outlined by the strategic plan; implementation of a competent marketing policy within a certain budget; maximum retention of staff; consistent advancement of the previously outlined social policy.

\section{Conclusion}

In the modern economy, business activity of enterprises is understood as the ability of an enterprise to achieve planned economic growth and development with the widespread use of the entire range of extensive and intensive methods to improve the efficiency of its activities.

In a detailed study of economic growth, the following areas for enterprises are often identified:

- time, which determines the dynamics of the most important indicators in time for the studied period of time, taking into account the rate of their change.

- $\quad$ industry, which determines the importance of an enterprise in the industry and the output of industry products;

- $\quad$ social, providing social guarantees to the employees of the enterprise when the macroeconomic conditions change (level of employment, crisis, inflation, etc.);

- innovative, in which a policy of improving the quality of products, their competitiveness, regular updating of technologies, means of labor, etc. is implemented.

When studying the business activity of enterprises, it is advisable to consider:

1. Planned growth and improvement of the material and technical base of production (fixed and circulating assets, staff).

2. Balance and consistent increase in the financial results of the enterprise.

3. Improving the efficiency of using all types of resources of the enterprise and its work as a whole, taking into account the use of extensive and intensive development factors. 
REVISTA DE LA UNIVERSIDAD DEL ZULIA. 3é época. Año $12 \mathrm{~N}^{\circ}$ 34, 2021

Lyudmila M. Putyatina et al. /// Business activity of enterprises as a factor in accelerating ... 133-149

DOI: http://dx.doi.org/10.46925//rdluz.34.09

4. Pursuing a policy of deepening specialization and diversification of production.

5. Growth of the innovative potential of the enterprise in all areas of activity (goods, technologies, means of production and communications, marketing, etc.).

6. Effective management of human resources based on advanced training, modern means of labor motivation, taking into account its effectiveness.

7. Conducting an effective financial policy to ensure liquidity, solvency and financial stability of the enterprise.

8. Improving the efficiency of enterprise cost management.

9. Ensuring competent and effective promotion of goods in the markets of relevant products.

10. Growth of the business reputation of the company and positioning in the industry environment based on competitive advantages.

The market stability of an enterprise is determined by its ability to fairly quickly restructure to changes in market needs and market conditions, building up and demonstrating its competitive advantages in the industry environment.

Market stability is manifested in the following indicators:

1. Maintaining industry specialization and consistently increasing market share for main products.

2. Dynamics of growth in the share of goods with a high level of competitiveness, confirmed by various awards and diplomas at industry exhibitions.

3. High level of self-financing of the enterprise development, i.e. the self-financing ratio exceeds $70 \%$, while determining high development opportunities at the expense of its own funds and has investment attractiveness.

4. Active participation in national, regional, sectoral projects in promising areas of development of the country's economy on a competitive basis, etc.

\section{References}

Abramsky, E.A. (2001). Currency market. Fundamental and technical analysis. Khabarovsk: Far Eastern Institute of International Business.

Abryutina, M.S., \& Grachev, A.V. (2001). Analysis of the financial and economic activities of the enterprise. Moscow: Business and service. 
REVISTA DE LA UNIVERSIDAD DEL ZULIA. 3é época. Año $12 \mathrm{~N}^{\circ}$ 34, 2021 Lyudmila M. Putyatina et al. /// Business activity of enterprises as a factor in accelerating ... 133-149 DOI: http://dx.doi.org/10.46925//rdluz.34.09

Atkisson, A. (2015). How sustainable development can change the world. Moscow: Binomial. Knowledge lab.

Azrilian, A.N. (2004). Big economic dictionary. Moscow: Institute of New Economy.

Bank, V.R., Bank, S.V., \& Taraskina, A.V. (2006). The financial analysis. Moscow: Business and service.

Dontsova, L.V. (2015). Analysis of accounting (financial) statements. Moscow: Business and Service.

Efimova, O.V., \& Melnik, M.V. (2009). Analysis of financial statements: textbook. manual for university students studying in the specialties "Finance and Credit", "Accounting, Analysis and Audit". Moscow: Omega-L.

Helfert, E. (2008). Financial Analysis Technique: The Way to Business Value Creation. Saint Petersburg: Piter.

Khotinskaya, G.I. (2018). Business activity of business as a factor of economic growth. Pricing models and financial instruments. Moscow: RuScience.

Kiselev, A.P. (2006). Theory and practice of modern business. Kiev: Libra.

Komarova, N.V., Zamkovoi, A.A., \& Novikov, S.V. (2019). The Fourth Industrial Revolution and Staff Development Strategy in Manufacturing. Russian Engineering Research, 39(4), 330-333. https://doi.org/10.3103/S1068798X19040105

Kovalev, V.V. (2007). Finance. Moscow: Prospect.

Kovalev, V.V., \& Volkova, O.N. (2000). Analysis of the economic activity of the enterprise: textbook. Moscow: Prospect.

Myasnikova, O.V. (2007). Statistical study of business activity (for example, retail trade and transport). Saint Petersburg: Saint Petersburg University of Economics and Finance.

Novikov, S.V. (2018). The features of innovative processes in the Russian Federation: Analysis of current practices. Espacios, 39(39), 2.

Petrova, V.I. (2020). Analysis of the economic activity of a machine-building enterprise. Moscow: Mechanical Engineering.

Pinkovetskaia, I. S., Aleksandrova, N. R., Treskova, T. V., \& Veas Iniesta, D. S. (2021). Present Innovation Policy: Russian Regions Data. Cuestiones Políticas, 39(69), 146-163. https://oi.org/10.46398/cuestpol.3969.08

Poloskov, S.S., \& Zheltenkov, A.V. (2018). High-tech and high-tech enterprises and their positioning in a competitive environment. Bulletin of the Moscow State Regional University. Series: Economics, 2, 155-163. 
REVISTA DE LA UNIVERSIDAD DEL ZULIA. 3é época. Año $12 \mathrm{~N}^{\circ}$ 34, 2021 Lyudmila M. Putyatina et al. /// Business activity of enterprises as a factor in accelerating ... 133-149 DOI: http://dx.doi.org/10.46925//rdluz.34.09

Putyatina, L.M., \& Arsenyeva, N.V. (2020). The problem of market stability of machinebuilding enterprises in the modern economy. Economics, Entrepreneurship and Law, 10(3), 763744 .

Stone, D., \& Hitching, K. (2009). Accounting and financial analysis: a preparatory course. Saint Petersburg: Litera plus.

Voitolovsky, N.V., Kalinina, A.P., \& Mazurova, I.I. (2013). Economic analysis. Foundations of the theory. Comprehensive analysis of the organization's economic activities: a textbook for bachelors. Moscow: Urait.

Zverev, A., Mandron, V., Rebrina, T., Mishina, M., \& Karavaeva, Y. (2021). Investment policy of the banking sector: data from Russia. Amazonia Investiga, 10(42), 149-162. https://doi.org/10.34069/AI/2021.42.06.14 